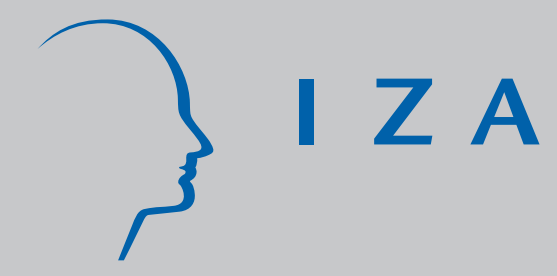

IZA DP No. 7263

The Relationship Between the Housing \& Labor Market Crises and Doubling-Up: An MSA-Level Analysis, 2005-2010

William H. Rogers

Anne E. Winkler

March 2013

Forschungsinstitut zur Zukunft der Arbeit Institute for the Study of Labor 


\title{
The Relationship between the Housing \& Labor Market Crises and Doubling-Up: An MSA-Level Analysis, 2005-2010
}

\author{
William H. Rogers \\ University of Missouri-St. Louis \\ Anne E. Winkler \\ University of Missouri-St. Louis \\ and IZA
}

Discussion Paper No. 7263

March 2013

\author{
IZA \\ P.O. Box 7240 \\ 53072 Bonn \\ Germany \\ Phone: +49-228-3894-0 \\ Fax: +49-228-3894-180 \\ E-mail: iza@iza.org
}

\begin{abstract}
Any opinions expressed here are those of the author(s) and not those of IZA. Research published in this series may include views on policy, but the institute itself takes no institutional policy positions. The IZA research network is committed to the IZA Guiding Principles of Research Integrity.

The Institute for the Study of Labor (IZA) in Bonn is a local and virtual international research center and a place of communication between science, politics and business. IZA is an independent nonprofit organization supported by Deutsche Post Foundation. The center is associated with the University of Bonn and offers a stimulating research environment through its international network, workshops and conferences, data service, project support, research visits and doctoral program. IZA engages in (i) original and internationally competitive research in all fields of labor economics, (ii) development of policy concepts, and (iii) dissemination of research results and concepts to the interested public.
\end{abstract}

IZA Discussion Papers often represent preliminary work and are circulated to encourage discussion. Citation of such a paper should account for its provisional character. A revised version may be available directly from the author. 


\begin{abstract}

\section{The Relationship between the Housing \& Labor Market Crises and Doubling-Up: An MSA-Level Analysis, 2005-2010*}

It is now well-established that the U.S. housing market crisis preceded the labor market crisis and that, in the wake of these crises, doubling-up and cohabitation increased and homeownership fell. What is less clear is what happened at the subnational level. This study reports on: 1) how the length, severity and relative timing of both the labor market and housing crises varied by MSA; and 2) the association between the timing of the labor market and housing crises and changes in homeownership and doubling-up at the MSA level. The analysis is conducted using data on 353 MSAs, with a focus on 12 MSAs, for the period 2005 (pre-crisis) through 2010/2011. MSAs are categorized into those where the housing market declined first, those where the labor market declined first, and those where the events were concurrent. The analysis reveals that: 1 ) in the majority of MSAs, the labor market declined first, contrary to the national pattern and the experience of the vast majority of large MSAs; 2) there is a clear relationship between greater regional housing distress and falling homeownership rates; and 3) somewhat surprisingly, the association between changes in doubling-up and these crises are fairly weak at the MSA level.
\end{abstract}

JEL Classification: R23, J12

Keywords: labor market, housing market, foreclosures, household formation

Corresponding author:

Anne E. Winkler

Department of Economics

University of Missouri St. Louis

1 University Blvd.

St. Louis, MO 63121

USA

E-mail: awinkler@umsl.edu

\footnotetext{
* The authors gratefully acknowledge research funding from the University of Missouri Research Board. Trung Ly provided expert research assistance. The authors are grateful for comments from Deborah Balser, David Rose, Robert Sorensen, participants at the UMSL College of Business Seminar Series, and participants at the Washington University Seminar Series on Work, Family, and Policy.
} 


\section{Introduction}

In early 2007, the most recent U.S. housing bubble burst. This was followed by the onset of the Great Recession and the deepest employment decline that the United States has experienced since the end of World War II (Goodman and Mance, 2011). In the wake of these events, media reports and research studies have documented increased "doubling-up" of families as ever greater numbers of young adults returned to their parents' homes or were slower to exit than in years past (Mykta and Macartney, 2011; Weimers, 2012; Pew Research Center 2010; and Elliot, Young and Dye, 2011). ${ }^{1}$ A sign of the times, a 2009 USA Today article began: "Love isn't all that's keeping family together today. The bruising housing market is too." Other reports have pointed to rising rates of cohabitation resulting from the economic crisis in addition to the secular rise that was already underway (Kreider, 2010).

While these national patterns are now well-established, the relative timing of the housing and labor market crises at the MSA level and the association of these events with household formation has not been fully studied. ${ }^{2}$ This study reports on: 1) how the length, severity and relative timing of both the labor market and housing crises varied by MSA; and 2) associations between the timing of the labor market and housing crises and changes in homeownership and

${ }^{1}$ Even prior to the recent housing and labor market crises, demographers had noted the increasing rate of return (and delayed departure) of young adults from their parents' home. These trends were exacerbated by the depth and length of the recent housing and labor market crises; see Setterston and Ray (2010).

${ }^{2}$ Prior examinations of timing at the subnational level largely focused on the housing market only. See Fereirra and Gyourko (2011) and Sinai (2012). One study which looked briefly at the association between the crises and doubling-up at the MSA level is Dunne (2012). 
doubling-up at the MSA level. The analysis is conducted using data on 353 MSAs, with a focus on 12 MSAs, for the period 2005 (pre-crisis) through 2010/2011.

In the study, MSA-level housing prices serve as a measure of overall housing conditions. The start of the housing crisis in a given area is identified by looking at when prices peaked and then began to fall. Similarly, the start of the labor market crisis in a given area is identified by looking at when employment peaked. Using information on the timing of each crisis, this study then looks at the relative timing of the crises for each of the 353 MSAs examined: whether the housing market crisis occurred first (the pattern which occurred for the nation as a whole), whether the labor market crisis occurred first (which, it turns out, is the pattern for a slight majority of MSAs), or if these events were concurrent. The relative timing of these crises appears to be a useful way to categorize MSAs. The MSAs where the housing market declined first have some distinct characteristics: many are among the largest MSAs (as measured by employment size) and the crises in these MSAs were among the most severe, both in terms of magnitude and duration. The second part of the study investigates the association between the labor market and housing crises at the MSA level and changes in doubling-up and homeownership. As would be expected, there is a strong association between greater regional housing distress and falling homeownership rates. Somewhat surprisingly, however, the association between changes in doubling-up and these crises appears fairly weak at the MSA level.

\section{Literature Review}

The collapse of the U.S. housing market in 2007 and the onset of the Great Recession spawned a tremendous amount of inquiry into the nature, causes, and consequences of these crises. The most relevant prior research can be divided into two parts: 1) studies that have 
looked at the labor market crisis or housing market crisis at the subnational level; and 2) studies that have looked at the relationship between these crises and household formation at the MSA level. Each literature is examined in turn.

A number of studies have examined the recent boom and subsequent bust in the national housing market. Dates on the start of the national boom vary, with possibilities suggested including 1996 and 2002 (Byun, 2010) and 1998 (Cohen et al. 2012). There is a much narrower band around the date when the national house bubble burst, either mid 2006 using the Case/Schiller Housing Index or first quarter 2007 using the Housing Price Index from the Federal Home Financing Agency (Cohen et al. 2012). Turning to subnational data, Cohen et al. (2012) and Sinai (2012) point to considerable dispersion across MSAs in the magnitude of the rise in prices during the boom as well as dispersion in the decline of prices during the bust. Both studies find a similar set of patterns: 1) MSAs located in the interior of the United States (e.g. Charlotte, Detroit, Cleveland, and Chicago) experienced smaller increases in housing prices during the boom than those located on the coasts; and 2) the set of MSA that experienced larger booms also tended to be those that experienced larger busts. Among the interesting exceptions (see Cohen et al, 2012), the rise in house prices in Las Vegas during the boom (150\%) was not quite as large as for other west coast cities (Los Angeles and San Diego at over 212\%), while the decline in housing prices during the bust was considerably larger than these counterparts (62\% versus around $40 \%)$.

Some housing studies have also looked at subnational variation in the timing of booms and busts including Case and Schiller (2003), Fereirra and Gyourko (2011), and Sinai (2012). Sinai (2012) is the most relevant here because he not only looked at the timing of the most recent housing boom, but also at the timing of the housing bust, and moreover, drew comparisons with 
the housing cycle of the 1980s. Interestingly, he found that the timing of the most recent housing bust in MSAs was more closely concentrated than the prior bust, with many peaks around 2007 and 2008, though there was still a good deal of heterogeneity. He did not, however, look at more finely grained data (quarterly) or consider variation in the timing of events in the labor market relative to the housing market by MSA as done here.

Extensive evidence also points to substantial heterogeneity in employment conditions at the subnational level. Especially hard hit MSAs include Detroit, Las Vegas, Los Angeles, and Miami (BLS, LAUS website). With the notable exception of Detroit, quite a few of these MSAs overlap with the MSAs associated with the housing bubble (Lerman and Kingsley, 2010). This is to be expected given the strong relationship between the housing sector and construction employment (Byun, 2010). Less attention, however, has been paid to regional variation in the timing of employment crises though Wall (2010) is a notable exception. In his study, Wall (2010) examined the timing of economic expansions and downturns employment for a small number of cities. He found that cities experienced these events at around the same time as the nation, but nevertheless still identified quite a bit of dispersion, similar to the conclusion reached by Sinai (2012) regarding variation in the timing of housing crises at the MSA level.

Finally, a few prior studies have sought to explicitly link changes in the housing market and/or labor market during the recent crisis to changes in household formation at the MSA level. ${ }^{3}$

\footnotetext{
${ }^{3}$ As noted at the outset, in recent years, quite a few studies have identified a relationship between the advent of the Great Recession and doubling-up at the national level. Prior to the recent crisis, a substantial body of social science research focused on the relationship between housing conditions and household formation decisions of individuals, principally young adults and single mothers. Such studies include Borsch-Supan, 1986; Card and Lemiuex, 1999; Ermisch, 1999; Furstenberg, 2010; Goldsheider and DaVanzo, 1989; Haurin and Rosenthal, 2008; Winkler, 1992; Yelowitz, 2007; and Zhu and Liu, 2006.
} 
Dunne (2012) used MSA-level data on persons age 18-34 to investigate the correlation between household formation (e.g. headship rates and number of households) and labor market conditions and the correlation between household formation and housing prices. He found that doubling-up is associated to some extent with both weak housing and labor markets, but did not probe further. Painter (2010) used data on 80 MSAs from the American Community Survey (ACS) for 20052008 to examine changes in household headship, homeownership, and overcrowding within a dwelling for MSAs grouped by immigrant status. Consistent with national data cited earlier, he found that headship rates and overcrowding rose while homeownership declined for all groups examined, though to differing extents.

A few other regional studies are less directly related but still worthwhile mentioning. Dettling and Kearney (2011), for instance, looked at the impact of variations in housing prices during the recent crisis on fertility using MSA-level data. And, a number of studies have looked at spillover and contagion effects of the foreclosure crisis that accompanied the housing price bubble burst. Such papers include Mian, Sufi and Trebbi (2011), Rogers (2009), Rogers and Winter (2010), and Harding, Rosenblatt and Yao (2009).

To sum up, this study builds upon earlier studies of subnational housing and labor markets and documents geographic differences in the timing and severity of the labor market and housing crises of the late 2000s. It then takes a further step and examines associations between these events and household formation. 


\section{Data and Methodology}

The analysis is conducted using data on 353 MSAs, with a particular focus on 12 MSAs, for the period 2005-2010/11. ${ }^{4}$ The rationale for the selection of these specific MSAs is discussed shortly. Table 1 summarizes the key indicators and their sources. Labor market conditions are principally measured using BLS data on nonfarm employment. ${ }^{5}$ Overall conditions in the housing market are measured using the Federal Housing Finance Agency (FHFA) housing price index for single-family units. ${ }^{6}$ In the analysis, the index is set to have a base year of $2005=100$. These data are available at the quarterly level through 2011. Prior studies examining changes in overall housing conditions across MSAs have similarly used these data or relied on a smaller set of MSAs included in the Case-Schiller Index (see Sinai, 2012; and Cohen et al. 2012).

Some attention is also focused on foreclosures given the acute impact they had on particular housing submarkets (e.g. subprime loans). Foreclosures are measured using

\footnotetext{
${ }^{4}$ There are 367 total MSAs (Metropolitan, Micropolitain, and Metro Divisions) in the FHFA housing price index series. The figure is then slightly reduced to 353 due to data availability for selected years in two other databases used here: CoreLogic and the annual ACS.

${ }^{5}$ The advantage of looking at employment (or the reverse, nonemployment) rather than unemployment is that it provides information on those who hold (or do not hold) jobs, regardless of their search activity. Figure 1 (only) provides information on both.

${ }^{6}$ FHFA constant-quality housing prices are constructed using a repeat-sales method (similar to the Case-Shiller Index), where sales observations are not included unless the housing unit has been sold at least twice in the data series. One characteristic of a repeat-sales index is that previously published values are subject to change over time as existing housing units are sold a second time. Our analysis was conducted using data collected from FHFA in the summer of 2012. Thus, our calculated rates of change may not precisely match reported rates in current or future FHFA publications.
} 
proprietary data obtained from CoreLogic. ${ }^{7}$ CoreLogic includes 85 percent of foreclosures and first lien loans. A foreclosure is defined as a situation where ownership of the property is in the process of changing hands. The foreclosure rate is calculated here as foreclosures per number of loans (multiplied by 100). Foreclosure data are available at the monthly level, though in much of the analyses, they are aggregated to the quarterly (or annual) level for comparisons with data from other sources. For all non-annual data, seasonal adjustment is undertaken using a locally weighted regression (Cleveland et al. 1990).

Data on rates of doubling-up, cohabitation, and housing tenure (home ownership) are drawn from annual data for 2005 through 2010 from the American Community Survey (ACS). The prime advantage of the ACS is that it is the largest household survey in the U.S. with information on 3 million addresses. In all analyses, group quarters (e.g. dorms and institutional settings) are omitted as a household type. Using the ACS, two measures of doubling up are examined: average household size and the number of nonrelatives living in family households as a percentage of total number of persons residing in family households. ${ }^{8}$ For completeness, the study also examines homeownership rates, defined as the percent of all households that are owner-occupied. In interpreting these measures, homeownership rates reflect the investment component of housing demand while rates of doubling-up provide information regarding

\footnotetext{
${ }^{7}$ For a comparison with other sources of foreclosures, including RealtyTrac, see Mortgage Banker's Association (2008). The report by the Mortgage Banker's Association points to an important drawback of the oft-used RealtyTrac measure: it is subject to double-counting. While RealtyTrac only counts 1 filing per month (even if more than 1 occurs), if filings for the same property occur in different months, they count all such events.

${ }^{8}$ The Census Bureau defines a family household as a household in which there is at least one person present who is related to the householder by birth, marriage or adoption (Census Bureau website).
} 
consumption demand for housing (e.g. need for shelter). Finally, we also look at trends in the number of unmarried (opposite-sex) partner households as a percentage of total households. This latter measure is a bit different than doubling-up per se and provides information about the marriage versus cohabitation decision. While cohabitation rates have been experiencing a secular increase, economic conditions also play an important role, given evidence that couples are more likely to defer a wedding and legal marriage until they are able to afford it (Smock et al. 2005).

The empirical analysis proceeds in two parts. First, the severity and relative timing of the housing and labor market crises are examined for the 353 MSAs for which we have complete data. This analysis is conducted using quarterly data from $3^{\text {rd }}$ quarter 2005 through $2011 .^{9}$ This analysis further focuses on the experience of $12 \mathrm{MSAs}$ with distinct differences in the relative timing of their housing and labor market crises. The second part of the analysis investigates the association between the housing and labor market crises and changes in homeownership and doubling-up. In this second portion of the analysis, the quarterly data on the housing and labor market variables are annualized to match the annual data available in the ACS.

\section{Descriptive Analysis}

\section{A. National Picture}

Before proceeding to the analysis of MSAs, Figure 1 provides information on national U.S. labor market and housing market conditions from 2005 through 2011 . Housing prices in the nation accelerated during the early to mid 2000s, reaching a peak in first quarter 2007 based on

\footnotetext{
${ }^{9}$ The foreclosure data obtained by the authors from CoreLogic begin in $2^{\text {nd }}$ quarter 2005 and so all analyses use this period as the start date.
} 
the FHFA housing price index. ${ }^{10}$ From annual 2007 to 2010 , housing prices declined nearly 13 percent on average in the U.S. as a whole and the foreclosure rate, a measure of acute housing distress, rose from .87 to $3.26 \%$, a whopping $274 \%$ increase. Trends in U.S. employment and unemployment are mirror images and both show a downturn in the labor market by the end of 2007/early 2008. From 2007 to 2010, the unemployment rate rose from 4.6 to 9.6 percent, while employment fell by $5.6 \%$. The data also show that the start date of the Great Recession of December 2007, as determined by NBER, virtually coincides with the start of the labor market downturn. As shown in Figure 1, the national situation from 2005 to 2011 can be described as four distinct periods: the pre-crisis period (prior to 2007), the housing-crisis only period ( $1^{\text {st }}$ quarter 2007-end of 2007), the housing-recession period (end of 2007-summer 2009) and the post-recession period (after summer 2009). Even as of the end of 2012, the national unemployment rate still remained only slightly below 8 percent.

In terms of timing of the labor market and housing market crises, Figure 1 shows the well-known story for the United States: the start of the housing crisis, as defined by the fall in housing prices, preceded the downturn in the labor market. We term this sequence of events as: "housing market crisis first, labor market crisis second." As we will see, this is also the sequence of events for a number of the largest, but not the majority, of MSAs.

\footnotetext{
${ }^{10}$ Case and Quigley (2010), who describe the boom as being of "historical proportions," provide a succinct discussion of the unique set of events that precipitated the boom and lead to the subsequent bust.
} 


\section{B. MSA-Level Picture: An Overview}

Figure 2 illustrates annual trends in employment and housing conditions for all 353 MSAs (unweighted) for 2005 through 2010. These trends closely match those for the nation (MSAs weighted by population size) reported in Figure 1. Most notably, Figure 2 again shows that the housing crisis started first, followed by the labor market crisis. The top panel of Table 2 provides annual statistics for two specific years shown in Figure 2, 2007 and 2010. Statistics for 2007 are presented rather than 2005 because most MSAs still experienced rising employment and housing prices prior to $2007 .{ }^{11}$ This table shows that housing prices fell on average by nearly 10\% across the 353 MSAs between 2007 and 2010. This average decline is slightly lower than for the nation as a whole (Figure 1) because these figures are unweighted and thereby reflect the fact that housing prices declined less in smaller MSAs. ${ }^{12}$

Figure 2 and the top panel of Table 2 also provide information on annual trends in homeownership rates, measures of doubling-up, and percent of unmarried households for the 353 MSAs. As documented by research on national trends cited earlier, the figure and table also show that doubling-up increased, whether measured by higher average household size or nonrelatives as a percentage of all individuals living in family households. The fraction of unmarried households also rose over this period, in part because of the rising secular trend, but also due to weak economic conditions (Kreider 2010). Finally, Table 2 shows that homeownership rates fell in conjunction with the decline in housing prices and with the rise in

\footnotetext{
${ }^{11}$ Of course, as emphasized in this study, the date of each crisis and which came first varied considerably by MSA, so the choice of 2007 is for convenience of presentation only.

${ }^{12}$ Sinai (2012) also points to a similar pattern of findings in his comparison of the severity of housing declines based on weighted and unweighted MSAs.
} 
foreclosures. While suggestive, these aggregate data mask substantial subnational variation in the severity, duration, and timing of the crises as well as obscure the considerable heterogeneity in changes in doubling up and homeownership at the subnational level.

\section{C: MSA-Level Analysis: Timing of the Housing and Labor Market Crises}

This section examines the relative timing of the housing and labor market crises in each MSA. To do so, we first identify the start of each crisis by examining quarterly data from 2005 to 2011. A crisis in the housing market is identified when housing prices, a measure of overall housing conditions, peaks in a given quarter and then turns down. ${ }^{13}$ Similarly, a crisis in the labor market is identified when employment peaks in a given quarter and then subsequently falls. In the case that either the housing price or employment series has multiple peaks, the peak used is the one that precedes the longest downturn. ${ }^{14}$

Figure 3 provides a histogram of the relative timing of the crises, where differences in timing is measured in number of quarters, for the 353 MSA. A positive value indicates that the housing market crisis occurred first, while a negative value indicates that the labor market crisis. The distribution is slightly skewed to the left, indicating that in a slight majority of MSAs, it was the labor market, not the housing market that turned down first. This pattern is contrary to the

\footnotetext{
${ }^{13}$ More precisely, a crisis is identified when the series growth rate changes sign (e.g. indicating a switch from growth to decline).

${ }^{14}$ An alternative strategy is to identify the primary housing or labor market peak based on the magnitude of the change in prices (or employment) rather than based on duration. Most MSAs experienced multiple housing price peaks after the main downturn in their MSA's housing market. However, these housing price fluctuations were usually both small in magnitude and duration, which left the first housing price downturn as the clear peak of primary interest. Early sensitivity testing indicated that many, though not all of the same MSAs, are identified.
} 
experience for the U.S. taken as a whole, as shown in Figure 1. The reason for the difference is that the national picture is driven by timing patterns in the largest MSAs.

To illustrate this point, Table 3 provides information on relative timing for the 25 largest MSAs (based on employment size). In 20 out of largest 25 MSAs, the housing market declined first, and in 10 of these 20 MSAs, the housing market declined four or more quarters earlier. In the other 5 of the largest 25 MSAs, the labor market declined first and only Dallas experienced a decline of 4 or more quarters. Also, Table 3 shows that the timing of the start of the housing crisis for the largest MSAs is fairly close to the timing for the national as a whole (first quarter 2007). The MSAs identified in gray receive greater attention shortly.

The analysis next identifies MSAs that had clearly different experiences regarding the timing of crises. To do so, a "4 quarter rule" is imposed. MSAs are categorized as "Housing Crisis Clearly First" if the housing market turned down 4 or more quarters before the labor market. MSAs are categorized as "Labor Market Crisis Clearly First" if the labor market turned down 4 or more quarters first. As found earlier, a slightly larger number of MSAs (67 versus 55) experienced the labor market crisis first. ${ }^{15}$

Figure 4 imposes the 353 MSAs on a map of the United States and illustrates geographic differences in the relative timing of the crises. Blue indicates that the housing crisis occurred first, while red indicates that the labor market crisis occurred first. A comparison of the darkest

${ }^{15}$ Omitted MSAs are also those where the period (e.g. peak to trough or trough to peak) could not be clearly identified. Clear identification of the period requires: 1) one unit of time before the first peak (housing prices or employment); 2) one unit of time between peaks; and 3) one unit of time after the second peak (housing prices of employment), where unit of time refers to quarter or year, depending on the analysis. The omitted group includes a number of smaller MSAs plus Boston. Boston, for example, saw housing prices peak in the summer of 2005 and employment peak in 2008. When the data for Boston was aggregated to annual rates of change, to include household information, Boston no longer contained a pre-peak period and therefore was dropped. 
red and darkest blue MSAs provides the clearest information regarding distinct differences in geographic timing. What is most apparent is that a larger number of MSAs on the coasts experienced the housing market crisis first (more blue), while the MSAs in the central part of the U.S., including Texas, experienced the labor market crisis first (more red). The bifurcation by geographic region matches earlier findings by Cohen et al. (2012) and Sinai (2012), which looked at the magnitude of regional housing bubbles and subsequent bursts.

We next look at the experience of 12 selected MSAs. From the set of "Housing Crisis Clearly First" MSAs, the largest five MSAs (by employment) were selected: $\mathrm{NY}^{16}, \mathrm{DC}$, Phoenix, Minneapolis-St. Paul, and San Diego. Though not one of the largest MSAs of this type, Las Vegas was also selected given the considerable media attention it has received. From the set of "Labor Market Clearly First” MSAs, the largest six were chosen: Dallas, Buffalo, Birmingham, Columbia, Knoxville, and Greenville. What is quite apparent in comparing these two lists but nothing else is that MSAs where the housing crisis clearly occurred first are considerably larger, with the single exception of Dallas. ${ }^{17}$

Figures 5a and 5b next highlight the timing, length, and severity of the housing and labor market crises using quarterly data for 2005-2011 for the 12 selected MSAs. Severity of the housing market crisis is measured by percentage change in housing prices while the severity of the labor market crisis is measured by percentage change in employment. Since these series are measured in different units (housing price is an index and employment is in thousands of

\footnotetext{
${ }^{16} \mathrm{NY}$ refers to the metro division that includes New York City.

${ }^{17}$ Some notable cities are excluded from these figures. One exclusion already mentioned is Boston. Another is Los Angeles. While Los Angeles experienced the housing decline first, the labor market crisis occurred 3 quarters later, and so is not included based on the "4 quarter rule."
} 
persons), the percentage change reported for each in Figures $5 \mathrm{a}$ and $5 \mathrm{~b}$ is standardized as follows:

$$
\% \Delta \mathrm{X}_{\mathrm{it}} / \sigma_{\mathrm{xi}}
$$

where $\% \Delta X_{i t}=$ annualized percentage change in employment (or housing prices) for the ith MSA in quarter $\mathrm{t}$; and $\sigma_{\mathrm{xi}}=$ standard deviation of $\% \Delta \mathrm{X}$ within the MSA for the period 2005-2011.

As one example, consider the cell for employment in NY in $3^{\text {rd }}$ quarter 2005 in Figure 5a. The value reported in this cell is 1.35 standard deviations from zero and was constructed as $2.08 \%$ (annualized value of percentage change in quarterly employment in $3^{\text {rd }}$ quarter 2005 for NY) divided by $1.54 \%$ (standard deviation calculated across all quarters for NY for 2005-2011). For further ease of interpretation of Figures $5 \mathrm{a}$ and $5 \mathrm{~b}$, darker colors indicate a larger number of standard deviations in the measure from zero, with red indicating a worsening and green indicating an improvement in housing and/or labor market conditions. Both figures also include the U.S. (all 353 MSAs aggregated) in the top panel for comparison purposes.

Figure 5a focuses on the experience of the 6 selected "Housing Crisis First" MSAs. The timing of the crises can be seen by observing that the housing price series turns from green to red earlier (at least 4 quarters, as specified) than the employment series. Nonetheless, even among these six MSAs, there is still considerable variation. Las Vegas and San Diego experienced similar timing and relative magnitudes of change in housing prices and employment. Both saw housing prices peak well before employment, and their housing price declines were relatively stronger compared to the eventual employment declines. In terms of employment, even by 2011, 
employment had not yet picked up in Las $\operatorname{Vegas}^{18}$, but none of the housing markets in Figure 5a look strong in 2011. In contrast, the situation in Washington, DC is considerably better, especially where the labor market is concerned, most likely due to the substantial number of public sector jobs, which tend to be more recession-proof.

Figure 5b points to the six selected "Labor Market Crisis First" MSAs. While every MSA in Figure 5b experienced a downturn in the housing market, the crisis was generally far less severe in length and magnitude. In fact, the Dallas MSA was virtually unscathed, especially as compared to the other large MSAs identified in Figure 5a. Buffalo is a notable exception and experienced a particularly deep labor market downturn during middle of 2008 through 2009, though the housing market was little affected. ${ }^{19}$

The lower two panels of Table 3 provide annual data 2007 to 2010 on housing prices, employment and other measures for the full set of "Housing Crisis First" versus "Labor Market Crisis First" MSAs. On average, employment fell by a similar percentage in both types of MSAs, $5 \%$, over this period, while housing prices declined by $32 \%$ in "Housing Crisis First" MSAs but

18 In interpreting the magnitudes in the figure, it is important to keep in mind the standardization that is used. The housing collapse in Las Vegas would stand out even more if we used the standard deviation of the percentage change for all areas across the nation instead of the standard deviation in the percentage change for the MSA itself. Standardizing each value by MSA allows one to more quickly identify strong changes in the employment and housing price growth within each MSA. This approach also permits meaningful comparisons of timing and magnitude across MSAs.

${ }^{19}$ Buffalo is also notable in that it provides an example of the challenges in identifying peaks. Buffalo experienced two clear declines in employment: a small decline starting in 2006 and a larger decline starting in 2008. On the housing side, the decline in housing prices during the fourth quarter of 2009 is almost impossible to see, as growth started up again in 2010. It should be further noted that as of February 2013, FHFA reported a decline in housing prices in the first quarter of 2010 and not in 2009. This difference is due, in part, to an index calculation adjustment inherent in repeat sales methods. 
experienced almost no change in the "Labor Market Crisis First" MSAs. Table 3 also provides supplementary information on foreclosure rates. As would be expected given the differential trends in housing prices, foreclosure rates rose considerably more in "Housing Crisis First" MSAs.

\section{Relationship Between Labor Market \& Housing Market Crises and Trends in Household Formation at the MSA Level}

The final part of this study examines the association between the housing and labor market crises and household formation and homeownership by MSA. Table 4 presents pairwise correlations for all 353 MSAs and for the two types of MSAs. The correlation between changes in housing prices and changes in foreclosure rates is negative as expected (falling housing prices go hand in hand with rising foreclosure rates), and considerably stronger in "Housing Clearly First" MSAs (correlation of -.71) compared to the "Labor Market Clearly First" MSAs (correlation of -.235). Another fairly strong association identified in "Housing Clearly First" MSAs is between changes in housing prices and changes in homeownership rates. The correlation is around .46, as compared with .2 for all MSAs and those where the labor market fell first. Surprisingly, however, associations between changes in employment and changes in doubling-up and changes in housing prices and doubling-up are comparatively very weak and quite often not in expected directions across all 353 MSAs and by MSA type.

One explanation for why correlations between the crises and household formation are so weak at the MSA level may be because the preceding analysis does not take into account the fact that, as we have seen, the housing and labor market crises occurred at different points in time in each MSA. For instance, even among "Housing Crisis Clearly First" MSAs, some MSAs 
continued to experience rising housing prices through 2007, while in others they had already begun their decline. So, a final important step is to match the substantive period (recall that Figure 1 could be subdivided into 4 substantive periods) and the date. Table 5 takes a case study approach for two representative MSAs: Las Vegas (housing crisis first) and Dallas (labor market crisis first). Annual data (since household formation is studied too) for 2005 to 2010 are divided into three substantive periods of interest: 1) 2005-the first market's peak; 2) from the first market's peak to the second market's peak; and 3) from the second market's peak to 2010 . (Recall that a peak defines the start of a crisis.) In the case of Las Vegas, these translate into the following three time frames: 1) 2005-2006 (where 2006 refers to the housing market peak); 2) 2006 (housing market peak) - 2008 (labor market peak); and 3) 2008 (labor market peak 2010). A similar type of decomposition is done for Dallas. Since these substantive periods cover different numbers of years, all figures are reported as average annual percentage change to enable comparisons.

First consider the Las Vegas MSA. From 2005 - 2006, employment and housing prices were rising at annual rates of 4 and nearly 8 percent, respectively. At the same time, the homeownership rate rose by nearly 2 percent, and both average household size and the percentage of non-family members living in a family household were falling. Increases in the homeownership rate may be interpreted as reflecting rising investment demand for housing, while declines in doubling-up may be interested as reflecting an increase in the consumption demand for housing. ${ }^{20}$ In Period 2, when the housing crisis set in (only), employment growth slowed compared to the prior period, while housing prices fell by 15 percent and foreclosures

\footnotetext{
${ }^{20}$ Foreclosures increased considerably, but this because the base was initially so low (and so any increase translates into a large percentage).
} 
rose dramatically. In this period, the homeownership rate fell by 2 percent and average household size rose by 1.7 percent. And while the percentage of non-family members living in family households continued to fall, the decline occurred to a lesser extent (so the trend from Period 1 to Period 2 is nevertheless in the direction one might expect). The percentage of unmarried households continued to rise, although, surprisingly, at a lower rate. Finally, in Period 3, with both crises underway, employment fell by 2.7 percent, and housing prices fell by even more than in the prior period, by nearly 19 percent. And, as would be expected, the percentage of non-family members living in family households rose, as did the percentage of unmarried households. Household size also continued to increase, though not by as much as it did in period 2.

In Dallas, a "Labor Market Crisis First" MSA, changes in housing prices were far more modest as were changes in employment, consistent with Figures 5a and 5b (which generally showed less severe crises for this MSA type). Foreclosure rates rose by far less as well. During Period 2 (labor market crisis only) homeownership rates fell, but by Period 3 they did not decline much more. Also, what is quite interesting to note in Dallas is that in Period 3, when the housing market declined, this decline was very modest (just a $2 \%$ decline in prices) and employment was in fact growing again. The pick-up in employment may explain concurrent declines in Period 3 in both household size and the percentage of non-relatives living in family households. While this exercise suggests that isolating associations using information on substantive timing is a potentially useful strategy, it is important to keep in mind that these are just that - associations. 


\section{Conclusion and Future Directions}

This study used data on 353 MSAs, with a particular focus on 12 MSAs, for the period from 2005 to 2010/2011 to examine the relationship between the severity and relative timing of the housing and labor market crises and changes in household formation. While it is wellestablished that the U.S. housing market, as a whole, turned down prior to the labor market, this is the first study to look at relative timing of these crises at the subnational level. The analysis of the relative timing of crises in the labor market and housing market across MSAs showed that it was actually the case that in a slight majority of MSAs the labor market turned down first.

MSAs where the housing market declined first have some distinct characteristics: they are some of the largest areas (New York, DC), more often located on coasts, and experienced some of the most serious downturn in the housing and labor markets, whether measured by length of the crises, the magnitude of the decline in housing prices or employment, or the rise in foreclosures. Along with earlier work by Cohen et al. (2012) and Sinai (2012) on the recent housing market crisis, this study deepens our knowledge about the considerable heterogeneity in the experiences of MSAs, a phenomenon which is obscured when looking at the national picture or at just a handful of well-publicized MSAs.

The second part of the study examined the association between changes in the housing and labor markets and changes in doubling-up and homeownership. Declining housing prices were found to be strongly associated with declines in homeownership, especially in those MSAs where the housing crisis turned down first. However, somewhat surprisingly, the association between changes in doubling-up and the housing and labor market crises was found to be fairly weak at the MSA level. One explanation is that the timing of the crises, differed considerably across MSAs, necessitating more refined analyses, as undertaken here. Nonetheless, this study is 
just a first descriptive step. Other factors, such as migration and the age distribution of household heads are not accounted for and association is not the same as causation (which we cannot say anything about). A logical next step in this line of research is to take advantage of the heterogeneity in the experiences of MSAs--in terms of the severity, length, and timing of the recent housing and labor market crises, as identified here--and examine impacts on individual decisions regarding doubling-up, homeownership, and cohabitation. 


\section{References}

Armour, S. (2009, February 3). More families move in together during housing crisis.USA Today.

Borsch-Supan, A. (1986). Household formation, housing prices, and public policy impacts. Journal of Public Economics, 30, 145-164.

Byun, K.J. 2010. The U.S. housing bubble bust: impacts on employment. Monthly Labor Review 3-17.

Case K.E. and R.J. Shiller. (2003). Is there a bubble in the housing market?" Brookings Papers on Economic Activity 2, 299-342.

http://www.wellesley.edu/Economics/case/PDFs/HousingBusts.2009.pdf7

Card, D. and T. Lemieux. (1999). Adapting to circumstances: The evolution of work, school, and living arrangements among North American youth. In D. Blanchflower and R. Freeman(eds.), Youth Employment and Joblessness in Advanced Countries. Chicago: University of Chicago Press.

Cleveland, R.B., W. S. Cleveland, J.E. McRae, and I. Terpenning. (1990). STL: A seasonal-trend decomposition procedure based on loess." Journal of Official Statistics, 6, 3-73.

Cohen, J. P., C.C. Coughlin, and D.A. Lopez. (2012). The boom and bust of U.S. housing prices from various geographic perspectives." Federal Reserve Bank of St. Louis Review, 94 (5), 341367.

Dettling, L. J. and M.S. Kearney. (2011). House prices and birth rates: The impact of the real estate market on the decision to have a baby, NBER Working Paper No. 17485.

Dunne, T. (2012). Household formation and the great recession. Economic Commentary (Federal Reserve Bank of Cleveland).

Dunne, T. and G. Venkatu. (2009). Foreclosure metrics. Economic Commentary (Federal Reserve Bank of Cleveland).

Ermisch, J. F. (1999). Prices, parents, and young people's household formation. Journal of Urban Economics, 45, 47-71.

Ferreira, F. and J. Gyourko. (2011). Anatomy of the beginning of the housing boom: U.S. neighborhoods and metropolitan areas, 1993-2009. NBER Working Paper No. 17374.

Furstenberg, F. F. (2010). On a new schedule: Transitions to adulthood and family change. Future of Children, 20, 67-87. 
Goldscheider, F.K. \&. DaVanzo, J. (1989). Pathways to independent living in early adulthood:Marriage, semiautonomy, and premarital residential independence. Demography 26, 597-614.

Goodman, C.J. and S.M. Mance. (2011). Employment loss and the 2007-9 recession: An overview. Monthly Labor Review (April), 3-12.

Goodman, A. C. and B.C. Smith. (2010). Residential mortgage default: Theory works and so does policy. Journal of Housing Economics 19 (4), 280-294.

Harding, J.P., E. Rosenblatt, and V. W. Yao. (2009). The contagion effect of foreclosed properties. Journal of Urban Economics, 66, 164-178.

Haurin, D. R. \& Rosenthal, S. (2008). The influence of household formation on homeownership rates across time and race. Real Estate Economics, 35(4), 411-450.

Kreider, R. (2010, September 15). Increase in opposite-sex cohabiting couples from 2009 to 2010 in the Annual Social and Economic Supplement (ASEC) to the Current Population Survey (CPS). Retrieved from http://www.census.gov/population/www/socdemo/Inc-Opp-sex-2009-to2010.pdf

Lerman, R. and T. Kingsley. (2010). Metro areas suffering the worst housing shocks also lose the most jobs. Metro Trends (Washington DC: Urban Institute).

Mian, A., A. Sufi, F. Trebbi. (January 2011). Foreclosures, house prices, and the real economy. NBER Working Paper No. 16685.

Mortgage Bankers Association. (2008). Sources of foreclosure data. MBA Research DataNotes. Retrieved from http://www.mortgagebankers.org/default.htm.

Mykyta, L. and S. Macartney. 2011. The effects of recession on household composition: Doubling Up" and Economic Well-Being. U.S. Census Bureau. SEHSD Working Paper No. 2011-4. http://www.census.gov/hhes/www/poverty/publications/papers.html

Accessed 13 October 2012.

Painter, G. (2010, April). What happens to household formation in a recession. Retrieved from http://www.housingamerica.org/RIHA/RIHA/Publications/72429_9821_Research_RIHA_House hold_Report.pdf

Pew Organization. (2010). The return of the multi-generational family household. Retrieved from http://pewsocialtrends.org/files/2010/10/752-multi-generational-families.pdf

Rogers, W.H. (2010). Declining foreclosure neighborhood effects over time. Housing Policy Debate, 20(4), 687-706. 
Rogers, W.H. and W. Winter. (2009). The impact of foreclosures on neighboring housing sales. Journal of Real Estate Research, 31(4), 455-479.

Setterson, R.A. and B. Ray. (2010). What's going on with young people today? The long and twisting path to adulthood. Future of Children, 20, 19-41.

Sinai, T. (2012). "House Price Moments in Boom-Bust Cycles." Working Paper, Wharton School and NBER. Paper prepared for NBER's Housing and Financial Crisis Conference, November 17 and 18, 2011.

Smock, P., W. Manning and M. Porter. (2005). 'Everything's there except money': How money shapes decisions to marry among cohabitors." Journal of Marriage and Family, 67(3), 680-96.

U.S. Census Bureau website. http://www.census.gov/hhes/families/about/ (accessed 15 January 2013).

Wall, H. (2013). The employment cycles of neighboring cities." Regional Science and Urban Economics 43(1), 177-185.

Wiemers, E. (2012). The effect of unemployment on household composition and doubling-up. Working Paper, U. Mass-Boston.

Winkler, A. E. (1992). The impact of housing costs on the living arrangements of single mothers," Journal of Urban Economics, 32(3), 388-403.

Yelowitz, A. (2007). Young adults leaving the nest: The role of the cost of living. In S. Danziger \& C. E. Rouse (Eds.), The price of independence: The economics of early adulthood (pp.170-206). New York: Russell Sage.

Zhu, X. D. \& Liu, X. (2006). The effects of housing push factors and rent expectations on household formation of young adults. Journal of Real Estate Research, 28(2), 149-166. 
Figure 1. Trends in the U.S. Labor Market and Housing Market

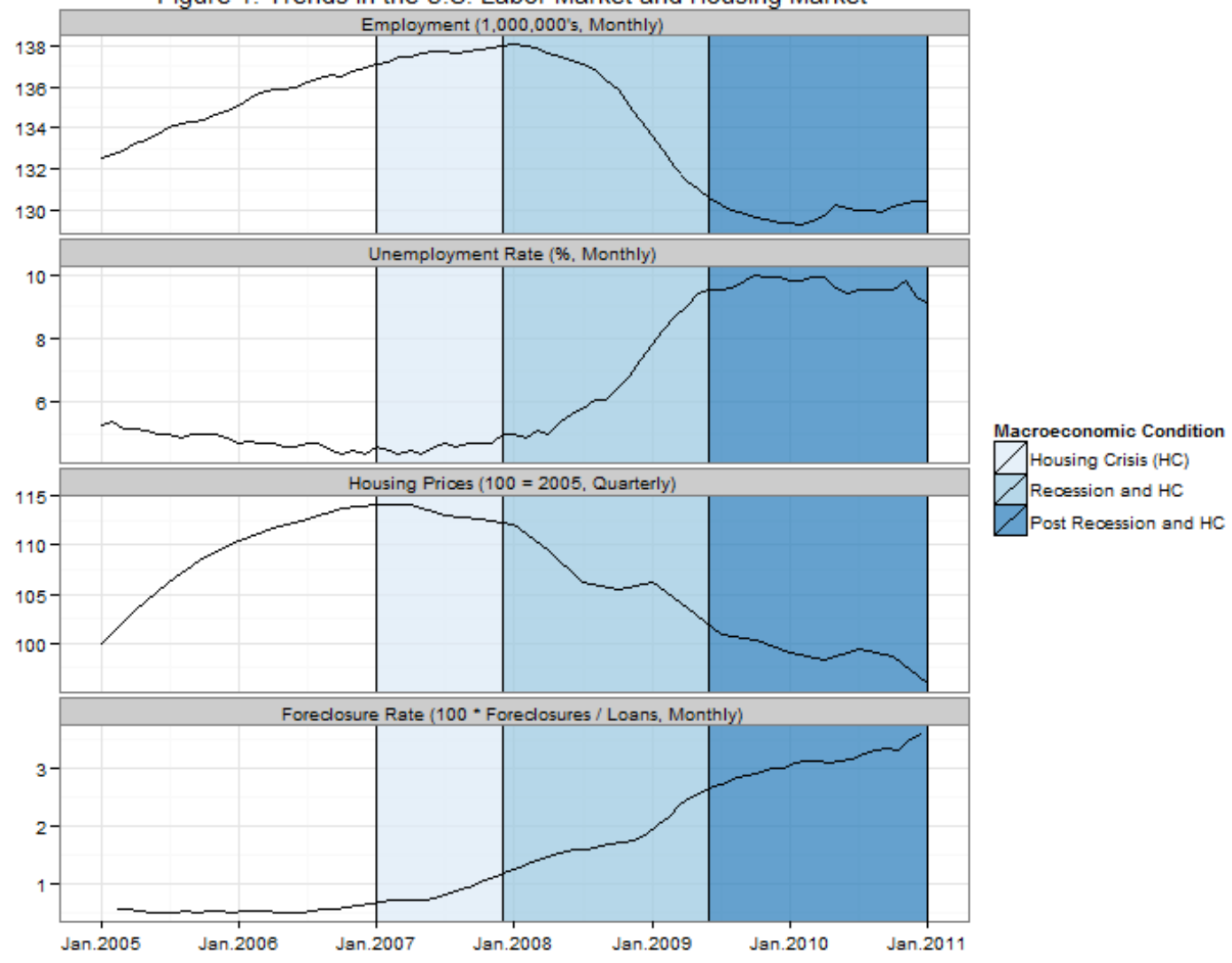


Figure 2. Trends in the U.S. Labor Market, Housing Market, and Measures of Doubling-Up, 2005-2010
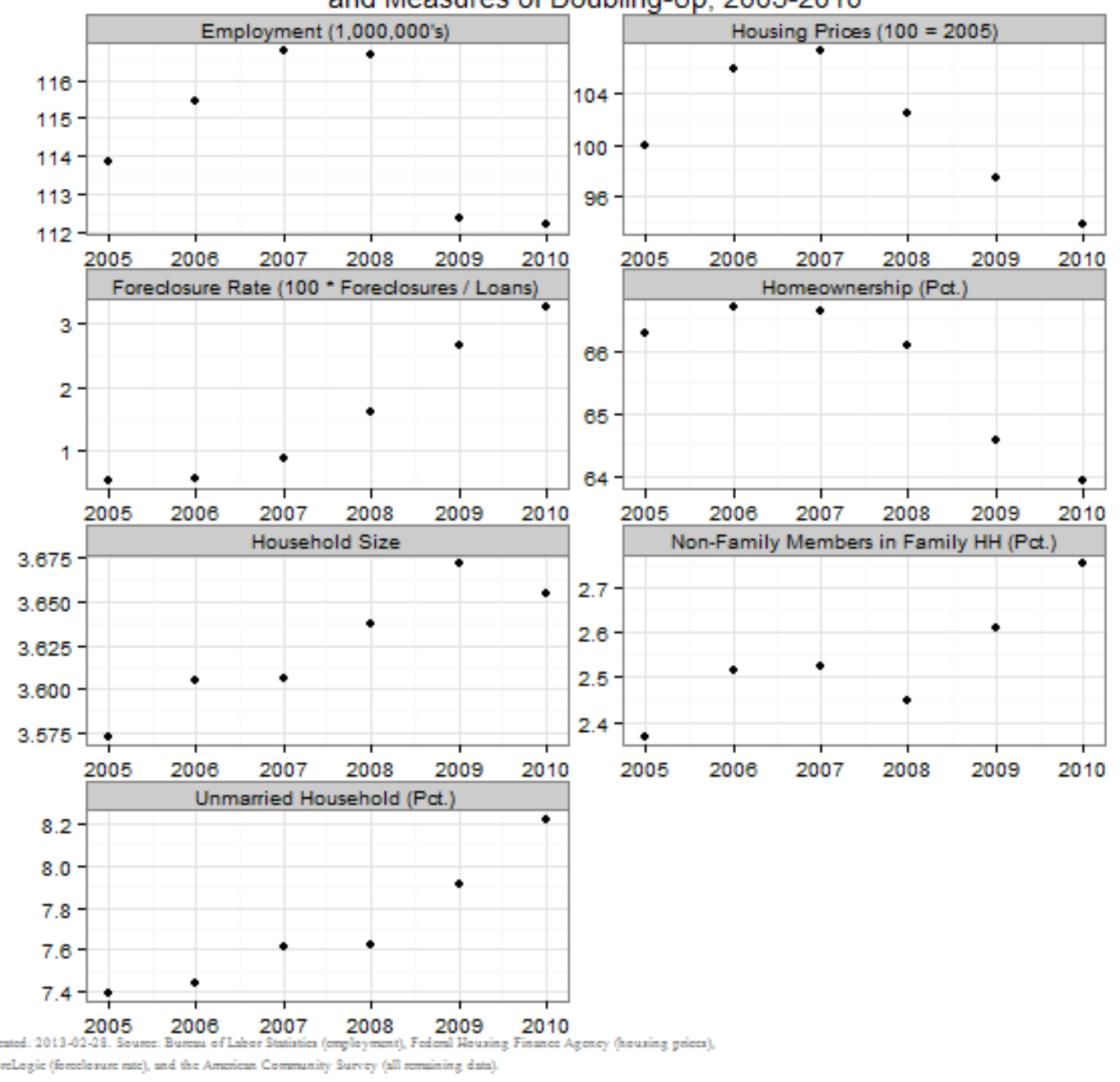


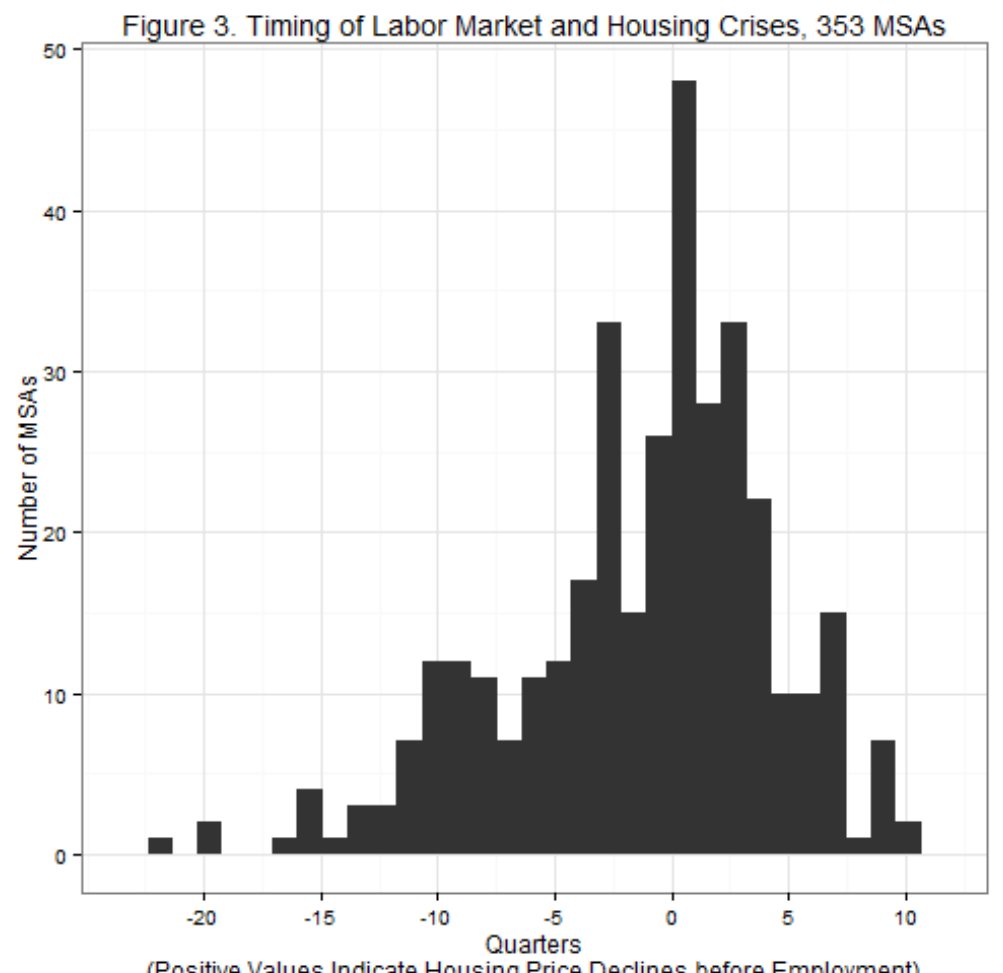

(Positive Values Indicate Housing Price Declines before Employment) 
Figure 4. Spatial Distribution of Labor Market and Housing Crises Timing, 353 MSAs

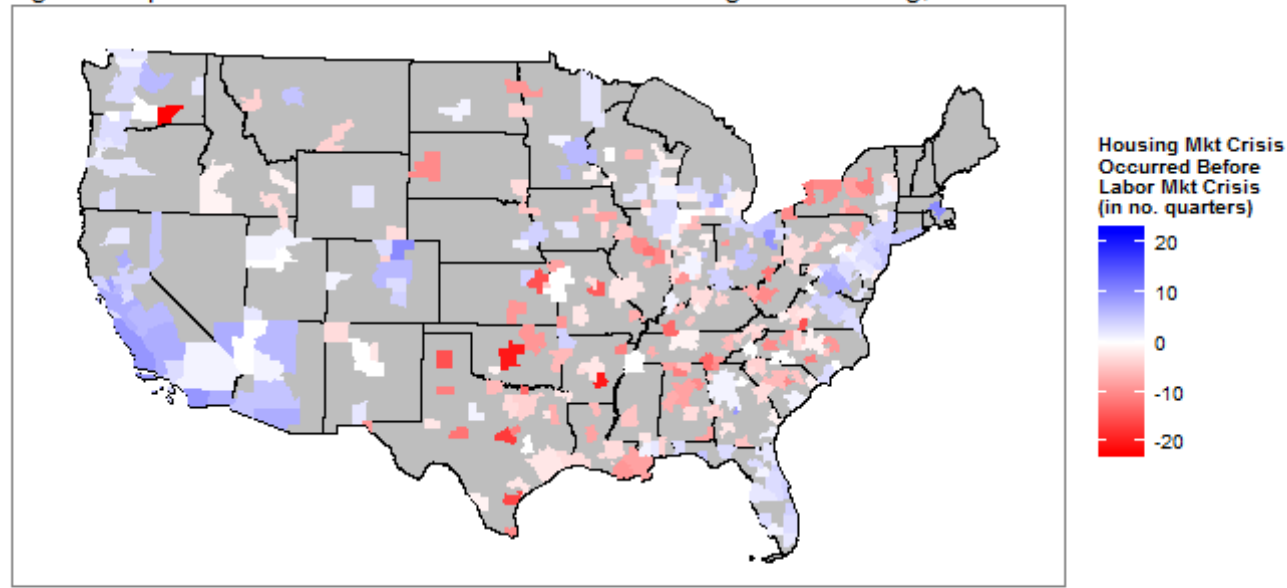


Figure 5 Panel A (Housing Crisis First). Timing of Labor Market and Housing Market Crises for Selected MSAs, Standardized Percent Change, 2005-2011

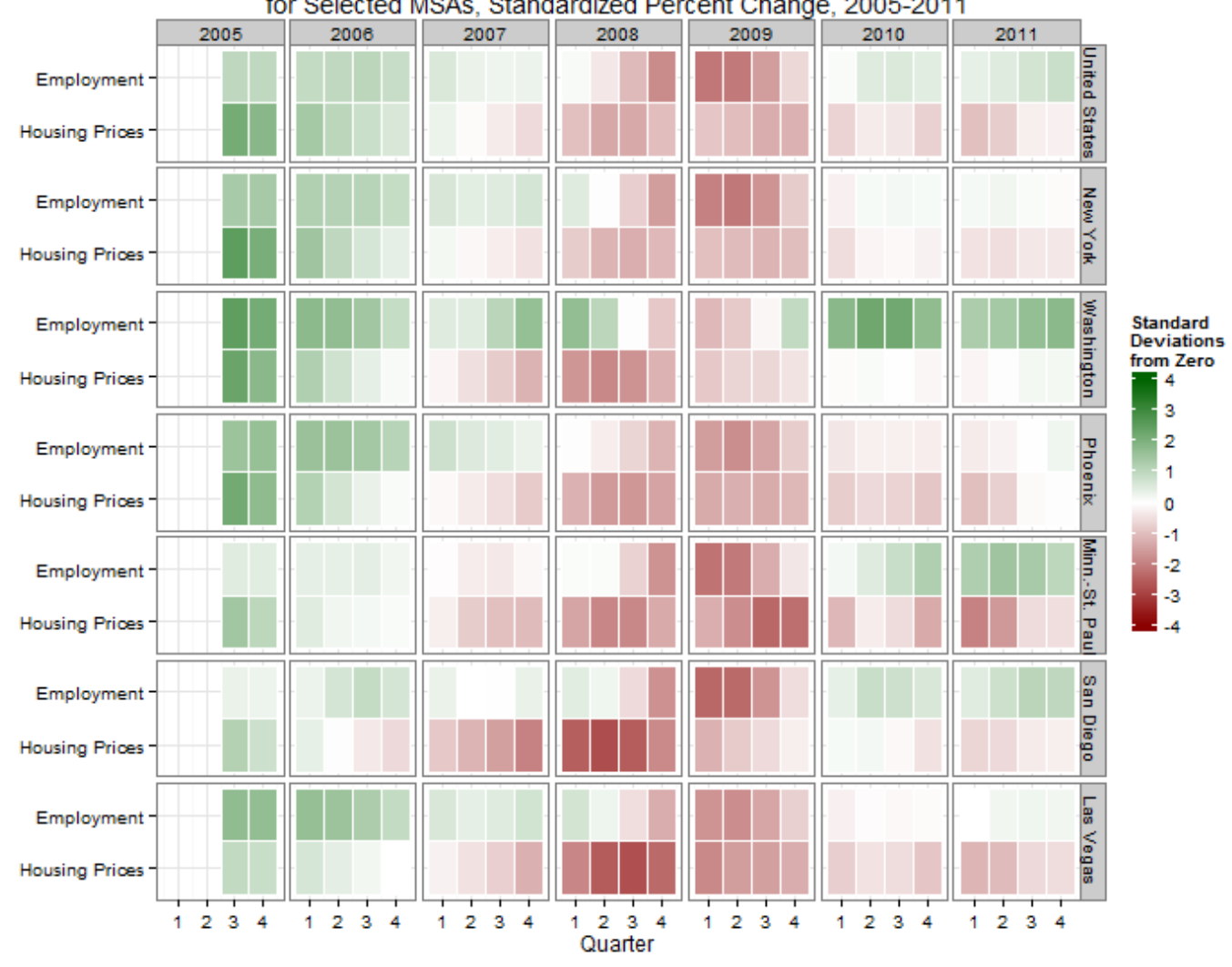


Figure 5 Panel B (Labor Crisis First). Timing of Labor Market and Housing Market Crises
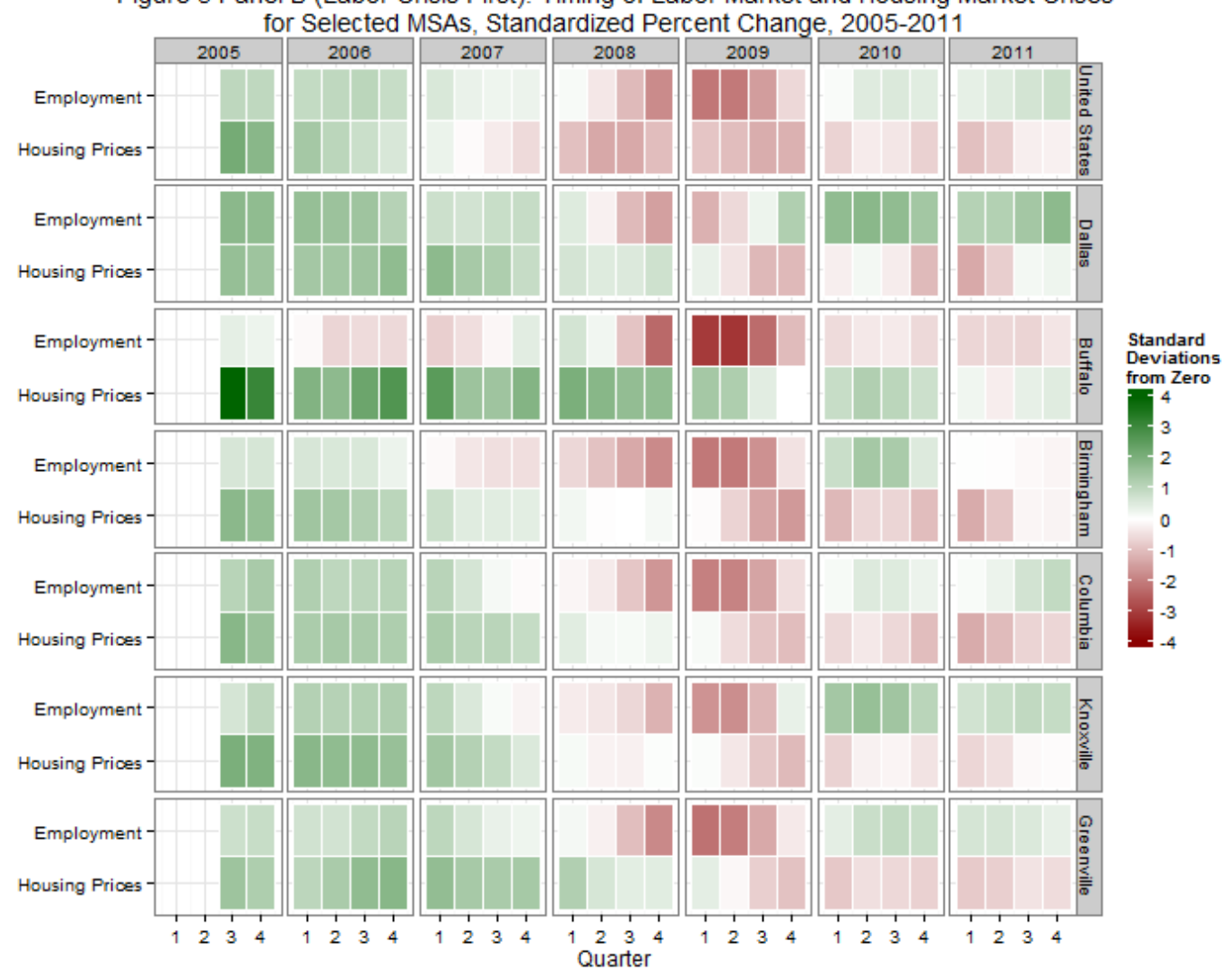
Table 1. Definitions of Housing Market, Labor Market, and Household Formation Variables

Measure

Definition

Household Formation and Home Ownership

Household Size

Nonrelatives as \% of Persons in Family Households

Unmarried Households as \% of Total Households

Home Ownership (\%)

Measures of Housing Conditions

Housing Price Index (Year $2005=100)$

Foreclosure Rate (\%)

CoreLogic

Measure of Labor Market Conditions

Employment Level (1000s)

Unemployment Rate
(Number of foreclosures/number of loans)*100; measure is akin to a default rate

FHFA

Size of household

Nonrelatives living in family households as \% of total persons in family households

Unmarried (opposite-sex) partner households as a \% of total households

Owner-occupied households as \% of total households

ACS

ACS

ACS

Nonfarm employment, age $16+$

Rate calculated for civilian noninstitutional population, age $16+$
BLS

BLS 


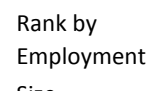

Size

MSA

New York-White Plains-Wayne, NY-NJ Metro Division; New York-Northern New Jersey-Long Island, NY-NJ-PA Metro Area

Los Angeles-Long Beach-Santa Ana, CA Metro Area

Chicago-Joliet-Naperville, IL-IN-WI Metro Area

Houston-Sugar Land-Baytown, TX Metro Area

Atlanta-Sandy Springs-Marietta, GA Metro Area

Washington-Arlington-Alexandria, DC-VA-MD-WV Metro Area

Dallas-Fort Worth-Arlington, TX Metro Are

Phoenix-Mesa-Glendale, AZ Metro Area

Philadelphia-Camden-Wilmington, PA-NJ-DE-MD Metro Area

Minneapolis-St. Paul-Bloomington, MN-WI Metro Area

Riverside-San Bernardino-Ontario, CA Metro Area

Los Angeles-Long Beach-Santa Ana, CA Metro Area

San Diego-Carlsbad-San Marcos, CA Metro Area

Boston-Cambridge-Quincy, MA-NH Metro Area

Nassau-Suffolk, NY Metro Division; New York-Northern New Jersey-Long Island, NY-NJ-PA Metro Area

St. Louis, MO-IL Metro Area

Baltimore-Towson, MD Metro Area

Seattle-Tacoma-Bellevue, WA Metro Area

Denver-Aurora-Broomfield, CO Metro Area

Detroit-Warren-Livonia, MI Metro Area

Tampa-St. Petersburg-Clearwater, FL Metro Are

San Francisco-Oakland-Fremont, CA Metro Area

Pittsburgh, PA Metro Area

Edison-New Brunswick, NJ Metro Division; New York-Northern New Jersey-Long Island, NY-NJ-PA Metro Area

Miami-Fort Lauderdale-Pompano Beach, FL Metro Area

${ }^{a}$ Positive figure indicates housing prices declined first; negative figure indicates that labor market declined first.

Notes: Shaded MSAs are analyzed further in Figures $5 \mathrm{a}$ and $5 \mathrm{~b}$. \begin{tabular}{l}
$\begin{array}{l}\text { Onset of } \\
\text { Housing Mkt } \\
\text { Crisis }\end{array}$ \\
\hline
\end{tabular}

1st Q, 2007

4th $Q, 2006$

1st Q, 2007

2nd Q, 2009

3rd Q, 2007

4th $Q, 2006$

1 st $Q, 2009$

4 th 0,2006

3rd Q, 2007

4th Q, 2006

4th $Q, 2006$

3rd Q, 2006

1st Q, 2006

4th Q, 2005

4th Q, 2006

3rd Q, 2007

2nd Q, 2007

3rd Q, 2007

4th Q 2006

3rd Q, 2005

4th Q, 2006

2nd Q, 2006

2nd Q, 2009

4th Q, 2006

2nd Q, 2007
Onset of

Labor Mkt

Crisis

1st Q, 2008

3rd Q, 2007

4th $Q, 2007$

4th $Q, 2008$

4th Q, 2007

3rd Q, 2008

1st Q 2008

1st $\mathrm{Q}, 2008$

2nd Q, 2008

2nd $Q, 2008$

1st Q, 2007

4th Q, 2006

2nd 2008

2nd Q, 2008

1st Q, 2008

1st Q, 2007

1st Q, 2008

2nd Q, 2008

2nd Q, 2008

2nd Q, 2005

2nd Q, 2007

1st Q, 2008

3rd Q, 2008

1st Q, 2008

4th Q, 2007
Housing Mkt Crisis

Occurred Before

Labor Mkt Crisis

(in no. of quarters) ${ }^{a}$ 
Table 3. Descriptive Statistics on All 353 MSAs, 2005 and 2010

\begin{tabular}{|c|c|c|c|c|c|}
\hline \multirow[b]{2}{*}{ All 353 MSAs } & \\
\hline & Mean & St.Dev. & Mininum & 50 Percent & Maximum \\
\hline Employment (thousands) & 325.2 & 573.6 & 29.1 & 123.5 & 5304 \\
\hline Housing Price Index (2005=100) & 108.2 & 8.0 & 90.6 & 107.3 & 137 \\
\hline Foreclosure Rate (\%) & 0.80 & 0.50 & 0.11 & 0.67 & \\
\hline Tenure (\% owned) & 68.0 & 5.7 & 41.0 & 68.9 & 82 \\
\hline Household Size & 3.50 & 0.23 & 2.63 & 3.48 & \\
\hline$\%$ Nonrelatives & 2.49 & 0.71 & 0.89 & 2.37 & \\
\hline$\%$ Unmarried Households & 7.75 & 1.87 & 2.16 & 7.80 & \\
\hline \multicolumn{6}{|c|}{ Housing Crisis Clearly First (55 MSAs) } \\
\hline Employment (thousands) & 576.8 & 850.7 & 29.1 & 210.9 & 530 \\
\hline Housing Price Index (2005=100) & 103.4 & 8.0 & 90.7 & 103.9 & 13 \\
\hline Foreclosure Rate (\%) & 0.87 & 0.48 & 0.12 & 0.80 & \\
\hline Tenure (\% owned) & 65.3 & 8.0 & 41.0 & 65.8 & \\
\hline Household Size & 3.63 & 0.26 & 3.08 & 3.63 & \\
\hline$\%$ Nonrelatives & 2.82 & 0.66 & 1.80 & 2.80 & \\
\hline \% Unmarried Households & 8.12 & 1.45 & 5.06 & 7.98 & 11 \\
\hline \multicolumn{6}{|c|}{ Labor Market Crisis Clearly First (67 MSAs) } \\
\hline Employment (thousands) & 142.3 & 247.9 & 39.1 & 74.5 & 1968 \\
\hline Housing Price Index (2005=100) & 107.9 & 3.8 & 102.5 & 107.2 & 12 \\
\hline Foreclosure Rate (\%) & 0.74 & 0.40 & 0.25 & 0.62 & 2. \\
\hline Tenure (\% owned) & 68.1 & 4.6 & 54.5 & 68.5 & \\
\hline Household Size & 3.44 & 0.19 & 3.08 & 3.43 & \\
\hline$\%$ Nonrelatives & 2.35 & 0.69 & 1.22 & 2.28 & \\
\hline$\%$ Unmarried Households & 6.97 & 2.06 & 2.45 & 6.93 & 12 \\
\hline
\end{tabular}

\begin{tabular}{c}
\hline Mean \\
\hline 312.5 \\
98. \\
2.51 \\
66. \\
3.5 \\
2.69 \\
8.22 \\
\\
559.2 \\
78. \\
3.60 \\
63. \\
3.69 \\
3.25 \\
8.49 \\
\\
137.9 \\
107.8 \\
1.62 \\
66.5 \\
3.51 \\
2.47 \\
7.87
\end{tabular}

2010

\begin{tabular}{lrrrr} 
& St.Dev. & \multicolumn{1}{c}{ Mininum } & 50 Percent & Maximum \\
\hline 312.5 & 549.8 & 28.6 & 116.7 & 5153.7
\end{tabular}

$\begin{array}{llll}16.9 & 41.5 & 103.1 & 148.5 \\ 2.23 & 0.49 & 1.93 & 17.71\end{array}$

$-9.97$

$\begin{array}{rrrr}16.9 & 41.5 & 103.1 & 148.5 \\ 2.23 & 0.49 & 1.93 & 17.71\end{array}$

68.11

$\begin{array}{rrr}2.23 & 6.1 & 39.5\end{array}$

67.1

17.71
81.5

$-2.40$

90.34

$\begin{array}{llll}0.21 & 3.06 & 3.55 & 4.40\end{array}$

1.54

$-2.58$

$\begin{array}{llll}1.89 & 1.66 & 8.17 & 13.88\end{array}$

5.72

9.38

4.79

$\begin{array}{rrrrrr}828.2 & 28.6 & 201.6 & 5153.7 & -3.15 & -4.42 \\ 17.7 & 41.5 & 81.5 & 124.7 & -32.60 & -21.53 \\ 2.57 & 0.82 & 2.80 & 13.20 & 75.96 & 251.48 \\ 7.8 & 39.5 & 63.4 & 81.5 & -3.29 & -3.66 \\ 0.22 & 3.25 & 3.66 & 4.24 & 1.43 & 0.67 \\ 0.78 & 1.79 & 3.10 & 5.87 & 13.31 & 11.05 \\ 1.59 & 5.25 & 8.40 & 11.84 & 4.30 & 5.30\end{array}$

$-4.42$

51.48

$-3.66$

11.05

$\begin{array}{llll}1.59 & 5.25 & 8.40 & 11.84\end{array}$

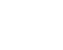

$\begin{array}{rr}248.8 & 37.3 \\ 5.5 & 93.8 \\ 0.64 & 0.67 \\ 5.6 & 48.2 \\ 0.19 & 3.06 \\ 0.57 & 1.23 \\ 1.81 & 3.49\end{array}$

71.1
107.8
1.51
67.4
3.52
2.38
8.03

1987.9

$-3.19 \quad-4.57$
-0.10

$\begin{array}{ll}-0.10 & 0.57\end{array}$

$54.29 \quad 144.68$

$-2.43 \quad-1.61$

$\begin{array}{ll}2.16 & 2.69\end{array}$

Notes: These data are unweighted.

Omitted MSAs are those where the housing and labor market crises occurred concurrently (defined as less than 4 quarters difference) and a small number where peaks could not be clearly identified. 
Table 4. Correlations between Labor Market, Housing Market, and Household Formation (all variables measured as \% change of original units)

\begin{tabular}{|c|c|c|c|c|c|c|c|}
\hline \multicolumn{8}{|l|}{ All 353 MSAs } \\
\hline & Employ & H Price & Forecl. Rate & Home Own & HH Size & \% Nonrel \%Unmarr $\mathrm{HH}$ & \\
\hline Employment & \multicolumn{2}{|l|}{1} & & & & & \\
\hline Housing Price & 0.389 & 1 & & & & & \\
\hline Forecl. Rate & -0.1 & -0.71 & 1 & & & & \\
\hline Home Ownership Rate & 0.003 & 0.211 & -0.084 & 1 & & & \\
\hline HH Size & 0.06 & -0.067 & 0.222 & 0.124 & 1 & & \\
\hline$\%$ Nonrelatives & 0.122 & 0.083 & -0.052 & -0.064 & -0.058 & 1 & \\
\hline$\%$ Unmarried HH & 0.107 & 0.094 & -0.088 & -0.135 & -0.107 & 0.481 & 1 \\
\hline \multicolumn{8}{|c|}{ Housing Clearly First MSAs (55 MSAs) } \\
\hline & Emp & H Price & Forecl. Rate & Home Own & HH Size & \multicolumn{2}{|l|}{ Nonrelativ€ Unmarr $\mathrm{HH}$} \\
\hline Employment & \multicolumn{2}{|c|}{1} & & & & & \\
\hline Housing Price & 0.314 & 1 & & & & & \\
\hline Forecl. Rate & -0.232 & -0.712 & 1 & & & & \\
\hline Home Ownership Rate & 0.086 & 0.46 & -0.126 & 1 & & & \\
\hline HH Size & 0.055 & -0.051 & 0.4 & 0.254 & 1 & & \\
\hline$\%$ Nonrelatives & 0.153 & 0.22 & -0.187 & 0.174 & 0.04 & 1 & \\
\hline \% Unmarried $\mathrm{HH}$ & 0.012 & -0.034 & 0.217 & -0.019 & -0.029 & 0.306 & 1 \\
\hline \multicolumn{8}{|c|}{ Labor Market Clearly First MSAs (67 MSAs) } \\
\hline & Emp & H Price & Forecl. Rate & Home Own & HH Size & Nonrelative Unmarr HH & \\
\hline Employment & \multicolumn{2}{|l|}{1} & & & & & \\
\hline Housing Price & 0.5 & 1 & & & & & \\
\hline Forecl. Rate & -0.155 & -0.235 & 1 & & & & \\
\hline Home Ownership Rate & \multirow{2}{*}{$\begin{array}{l}0.054 \\
0.024\end{array}$} & 0.195 & 0.046 & 1 & & & \\
\hline HH Size & & -0.09 & -0.096 & 0.016 & 1 & & \\
\hline$\%$ Nonrelatives & 0.023 & -0.022 & -0.187 & 0.174 & 0.04 & 1 & \\
\hline \% Unmarried $\mathrm{HH}$ & -0.015 & -0.045 & -0.05 & -0.281 & 0.016 & 0.332 & 1 \\
\hline
\end{tabular}


Panel A: Las Vegas, NV, MSA Where Housing Market Crisis Clearly First

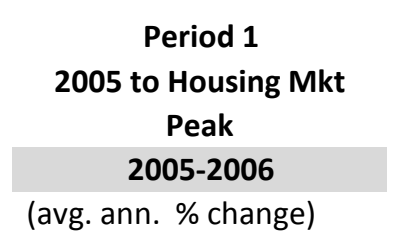

Employment (1000's)

Housing Prices $(100=2005)$

Foreclosure Rate (\%)

Homeownership Rate (\%)

Household Size

Non-Family Members in Family HH (\%)

Unmarried Household (\%)
Period 2

Period from Peak to

Peak

2006-2008

(avg. annual \% change)
Period 3

Labor Mkt Peak to 2010 2008-2010

(avg. ann. \% change)
Total Change

2005-2010

(avg. ann. \% change)

$0.36 \%$

$-12.43 \%$

$110.55 \%$

$-1.55 \%$

$0.69 \%$

$-0.10 \%$

$3.90 \%$

Panel B: Dallas, TX, MSA Where Labor Market Crisis Clearly First

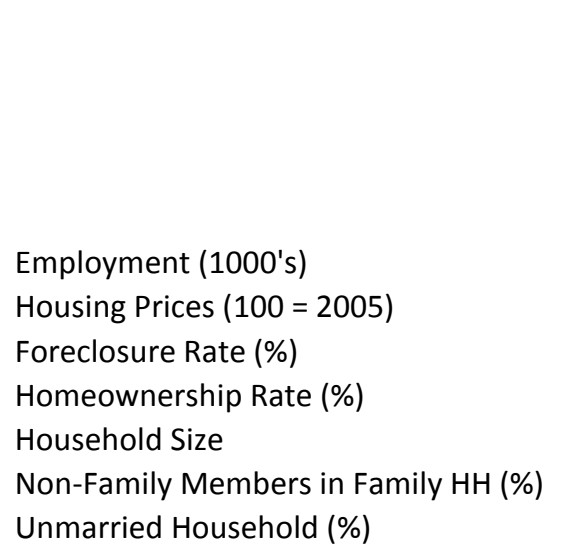

\begin{tabular}{|} 
Period 1 \\
2005 to Labor Mkt Peak \\
2005-2008 \\
(avg. ann. \% change) \\
$1.03 \%$ \\
$2.43 \%$ \\
$12.20 \%$ \\
$0.47 \%$ \\
$0.77 \%$ \\
$0.90 \%$ \\
$-5.39 \%$
\end{tabular}

Period 2

Period from Peak to

Peak

2008-2009

(avg. annual \% change)

$-1.31 \%$

$0.33 \%$

$30.62 \%$

$-1.73 \%$

$0.43 \%$

$16.42 \%$

$17.84 \%$
Period 3

Housing Mkt Peak to

2010

2009-2010

(avg. ann. \% change)

$1.89 \%$
$-0.98 \%$
$23.62 \%$
$-0.81 \%$
$-3.53 \%$
$-5.37 \%$
$3.40 \%$
Total Change

2005-2010

(avg. ann. \% change)

$0.73 \%$

$1.32 \%$

$17.93 \%$

$-0.23 \%$

$-0.17 \%$

$2.51 \%$

$0.63 \%$

Labor Market and Housing Market Peaks are identified in Figures $5 a$ and $5 b$ by quarter and then reassigned to the relevant calendar year. A peak is used to define the start of a crisis.

Calendar year data on all variables are provided in Appendix A. 
Appendix A. Underlying Data for Table 5.

Panel A: Data for Las Vegas, 2005-2010, annual

\begin{tabular}{|c|c|c|c|c|c|c|}
\hline & 2005 & 2006 & 2007 & 2008 & 2009 & 2010 \\
\hline Employment (1000's) & 838.9 & 873.2 & 890.1 & 902.4 & 864.4 & 854.0 \\
\hline Housing Prices $(100=2005)$ & 100.0 & 107.8 & 104.1 & 78.5 & 58.7 & 51.5 \\
\hline Foreclosure Rate (\%) & 0.22 & 0.41 & 1.36 & 3.28 & 6.61 & 8.97 \\
\hline Homeownership Rate (\%) & 59.5 & 60.5 & 58.6 & 58.2 & 56.9 & 55.0 \\
\hline Household Size & 3.63 & 3.55 & 3.58 & 3.67 & 3.66 & 3.75 \\
\hline Non-Family Members in Family HH (\%) & 3.69 & 3.50 & 3.79 & 3.26 & 3.66 & 3.68 \\
\hline Unmarried Household (\%) & 8.94 & 9.43 & 10.21 & 9.76 & 10.28 & 10.83 \\
\hline \multicolumn{7}{|l|}{ Panel B: Data for Dallas, 2005-2010, annual } \\
\hline & 2005 & 2006 & 2007 & 2008 & 2009 & 2010 \\
\hline Employment (1000's) & 1916.9 & 1946.0 & 1968.8 & 1976.8 & 1951.0 & 1987.9 \\
\hline Housing Prices $(100=2005)$ & 100.0 & 102.6 & 105.9 & 107.5 & 107.8 & 106.8 \\
\hline Foreclosure Rate (Foreclosures / Loans) & 0.65 & 0.65 & 0.73 & 0.91 & 1.19 & 1.47 \\
\hline Homeownership Rate & 61.0 & 62.1 & 62.7 & 61.9 & 60.8 & 60.3 \\
\hline Household Size & 3.78 & 3.84 & 3.85 & 3.87 & 3.89 & 3.75 \\
\hline Non-Family Members in Family HH (Pct.) & 2.19 & 2.36 & 2.34 & 2.25 & 2.62 & 2.48 \\
\hline Unmarried Household (Pct.) & 7.32 & 6.57 & 6.28 & 6.20 & 7.31 & 7.5 \\
\hline
\end{tabular}

Data used in conjunction with information on housing and labor market peaks to make computations in Table 5. 